\title{
KEGIATAN KEAGAMAAN SEBAGAI PILAR PERBAIKAN PERILAKU NARAPIDANA DI LEMBAGA PEMASYARAKATAN WANITA KELAS IIA SUNGGUMINASA GOWA
}

\author{
Herman Pelani \\ Bahaking Rama \\ Wahyuddin Naro \\ Email: pelaniherman53@gmail.com
}

\begin{abstract}
Abstrak: Penelitian ini membahas tentang kegiatan keagamaan sebagai pilar perbaikan perilaku narapidana di Lembaga Pemasyarakatan Wanita Kelas IIA Sungguminasa Gowa. Tujuan dari penelitian ini adalah untuk: 1) mengetahui kegiatan keagamaan di Lembaga Pemasyarakatan Wanita Kelas IIA Sungguminasa Gowa; 2) mengetahui faktor pendukung dan penghambat kegiatan keagamaan serta bagaimana hasil kegiatan keagamaan terhadap perilaku narapidana, wawasan pengetahuannya tentang ilmu agama dan perilaku kesehariannya baik sikapnya kepada sesama manusia dan ibadahnya selama di Lapas.
\end{abstract}

Jenis penelitian ini tergolong kualitatif dengan pendekatan penelitian adalah pendekatan ilmiah dan pendekatan studi keilmuan. Pendekatan ilmiah meliputi pendekatan sosiologis dan pendekatan studi keilmuan meliputi interdisipliner, yaitu pendekatan pedagogis dan pendekatan psikologis.

Hasil penelitian ini menunjukkan bahwa pelaksanaan kegiatan keagamaan sebagai pilar perbaikan perilaku narapidana di Lembaga Pemasyarakatan Wanita Kelas IIA Sungguminasa Gowa, berjalan dengan cukup baik dengan tenaga pembimbing uztadz dan uztadzah dari luar Lapas, yang memang dari latar belakang pendidikan Agama dari mulai jenjang S1 sampai S3. Ditunjang dengan fasilitas kegiatan keagamaan yang ada di Lapas, seperti Pesantren, Masjid dan perpustakaan, namun penulis melihat kegiatan keagamaan belum sepenuhnya berjalan dengan sangat baik karena penulis melihat ada beberapa faktor yang bisa menjadi faktor penghambat kegiatan keagamaan, misalnya masih ada beberapa narapidana yang tidak pernah dibesuk oleh pihak keluargnya sehingga narapidana tersebut tidak mempunyai biaya untuk membeli perlengkapan dalam melaksanakan kegiatan keagamaan, seperti mukena atau alat tulis untuk belajar. Masih minimnya suntikan dana kegiatan keagamaan dari pemerintah pusat, sehingga pihak Lapas selama ini masih banyak mengandalkan sumbangan sumbangan dari 
pihak dermawan yang menyumbang beberapa perlengkapan kepada para narapidana untuk beribadah, seperti Al-Qur'an, mukena.

\section{Keywords: Kegiatan Keagamaan; Perilaku Narapidana}

\section{PENDAHULUAN}

Manusia merupakan makhluk yang sangat istimewa, karena berbeda dengan makhluk lainnya. Manusia diberi akal pikiran dan segala potensi yang dimiliki untuk bertindak sesuai dengan etika dan nilai-nilai moral. Manusia adalah makhluk paripurna dengan segala aspek yang dimiliki yaitu aspek lahiriyah dan aspek batiniyah.

Kesempurnaan dan keistimewaan tersebut diharapkan manusia dapat hidup bahagia. Agama memiliki peranan yang sangat penting dalam kehidupan demi mencapai terciptanya kebahagian yang hakiki. Agama mempunyai pengaruh besar terhadap mereka yang meyakini kebenarannya. Namun realitanya jalan yang ditunjukkan agama tidak seluruhnya diikuti oleh manusia, bahkan sebagian besar mengingkarinya. Pengingkarannya terhadap agama ini tidak hanya terjadi pada zaman jahiliyah saja, tetapi terjadi pula pada zaman sekarang ini zaman yang dianggap serba modern. Proses modernisasi telah membawa perubahan pola hidup manusia. Terutama cara berfikir, bersikap dan bertingkah laku dalam kehidupan sehari-hari, perubahan tersebut akan membawa dampak positif dan negatif bagi setiap insan di dunia ini. Dampak negatif modernisasi antara lain: adanya perubahan tata nilai dan tata kehidupan yang serba keras, bahkan tradisi nenek moyang yang dikenal beradab bermoral dan beretika telah terkikis oleh budaya baru muncul yang tidak berlandasakan dengan Agama Islam.

Perubahan tata nilai kehidupan, dikarenakan sebagian manusia jauh dari perilaku yang baik dan cenderung perbuatanya bertolak belakang dengan norma Agama Islam dan mmengingkari apa yang telah ditetapkan oleh sang pencipta. Tentunya hal demikian tidak di inginkan terjadi. Banyak pemicu seseorang melakukan tindakan yang menyalahi aturan baik aturan dalam pandangan agama maupun hukum, salah satu pemicu seseorang melakukan berbagai hal yang bertentangan dengan agama yaitu tuntutan hidup yang semakin tinggi dan semakin banyak yang tidak terpenuhi, persaingan hidup semakin meningkat maka tidak jarang seseorang akan melakukan hal-hal yang mengakibatkan dirinya berurusan dengan hukum, apalagi seseorang yang tidak menjadikan agama sebagai way of life. ${ }^{1}$

Era modern ini seiring teknologi semakin canggih angka kriminalitas pun semakin bertambah tidak hanya di perkotaan, di desa pun angka kriminalitas semakin menjadi jadi dan sangat berkembang pesat, dijaman sekarang begitu

\footnotetext{
${ }^{1}$ Mohammad Ali Daud. Pendidikan Agama Islam. Ed.I; Jakarta: Rajawali Pers, 2008.
} 
mudahnya seseorang melakukan tindak pidana salah satu contoh tindak pidana yang terjadi dengan menggunakan kecanggihan teknologi yaitu, seseorang bisa bertransaksi atau melakukan perjudian dengan seseorang lainnya tanpa bertatap muka secara lansung, biasa disebut judi online, inilah salah satu perbuatan yang menyalahi atauran dengan menggunakan kecanggihan teknologi.

Salah satu dampak angka kriminalitas yaitu meningkatnya aksi kekerasan baik dilakukan secara individu maupun perbuatan kelompok yang mengakibatkan kerugian untuk orang lain. Dampak kriminalitas yang dilakukan oleh seseorang, menyebabkan Lembaga Pemasyarakatan dipenuhi dengan narapidana dengan berbagai macam tindak pidana, mereka harus menjalani hari harinya jauh dari sanak keluarga yang mereka cintai, karena harus menjalani hukuman. Mungkin tidak pernah dalam benak, terlintas mengenai hiruk pikuknya kehidupan di suatu lembaga pemasyarakatan atau rumah tahanan, dan tidak pernah dipikirkan tentang seorang wanita yang merupakan calon ibu yang akan melahirkan generasi penerus bangsa harus hidup berpuluh tahun di lembaga pemasyarakatan.

Tindak kriminal adalah suatu perbuatan yang tidak dibenarkan baik secara hukum apalagi dalam pandangan agama Islam, pelaku kriminalitas menurut pandangan penulis. Individu maupun kelompok yang sedang melakukan pencurian, pembunuhan, perampokan, pengedar sabu, pemerkosaan dan sebagainya, maka penulis menganggap bahwa mereka adalah pelaku kriminal tapi seseorang yang telah berhenti melakukan perbuatan seperti itu maka tidak lagi dikatakan sebagai pelaku kriminal. Kriminalitas pun terkadang tidak dilakukan dengan sendirinya dan terencana, terkadang karena terdesak oleh sesuatu yang harus mereka penuhi, seseorang ibu rumah tangga bisa saja melakukan tindak pidana pencurian karena terdesak oleh kebutuhan ekonomi, adapun seseorang melakukan tindak pidana bukan serta merta karena kenakalan ataupun karena akhlak yang buruk namun bisa saja karena seseorang membela diri akhirnya nekat membunuh seseorang. Jadi penulis beranggapan bahwa seseorang melakukan perbuatan kriminal bukan karena semata mata, terencana dan kemauan, namun adakalanya seseorang melakukan kriminal karena membela dirinya atau membela keluarganya yang tidsk bersalah. ${ }^{2}$

Kriminal terjadi terdiri dari beberapa faktor, seseorang melakukan perbuatan kriminal dengan dasar kemauan sendiri dipengaruhi oleh beberapa faktor yakni: Faktor ekonomi, sangat berpengaruh terhadap tingginya angka kriminalitas disebabkan kondisi bangsa Indonesia yang sebagian besar masyarakatnya masih di bawah angka kemiskinan, dan banyaknya pengangguran yang terjadi di mana-mana dikarenakan kurangnya keterampilan yang yang mereka ketahui, tuntutan akan kebutuhan hidup membuat sejumlah orang yang tertekan keadaan ekonominya, akhirnya nekat melakukan berbagai cara untuk

\footnotetext{
${ }^{2}$ Nasution Harun, Ensiklopedia Islam Indonesia Cet. I; Jakarta: Djambatan, 1992.
} 
mendapatkan uang, ditambah lagi keinginan untuk mendapatkan penghasilan dengan instan. Faktor narkoba, ketergantungan narkoba tidak menutup kemungkinan banyak fakta yang terjadi di lapangan menjadi faktor mengapa banyak orang yang nekat untuk melakukan aksi kejahatan juga didasari oleh kebutuhan dalam mencukupi efek ketagihan obat-obatan terlarang bagi mereka yang sudah menjadi pecandu. Faktor lingkungan, hal yang juga sangat mendukung dan membentuk karakter seseorang adalah lingkungan, mengapa seseorang baik lelaki maupun wanita berani melakukan tindak kejahatan adalah pengaruh lingkungan, karena lingkungan yang baik akan membentuk karakter yang baik dan lingkungan yang tidak baik akan membentuk karakter yang tidak baik. Faktor gaya hidup yang semakin bersaing apalagi diperkotaan, penghasilan yang tidak sesuai dengan biaya gaya hidup akan mudah menjadikan seseorang melakukan aksi kejahatan untuk mendapatkan apa yang mereka inginkan dengan jalan yang tidak benar. Beberapa tindak kriminal yang terjadi di Indonesia, penulis mengamati banyak terjadi di perkotaan.

Pada kondisi demikian, ketika seseorang berada pada jalan yang salah dan melakukan tindak pidana, maka tidak ada jalan lain selain mempertanggung jawabkan atas apa yang mereka telah perbuat. Negara Indonesia adalah negara hukum setiap warga negara yang melakukan tindak kejahatan harus mempertanggung jawabkan perbuatannya, seseorang yang telah melakukan tindak pidana akan ditentukan hukumannya melalui pengadilan, bagi seseorang yang memang melakukan kejahatan dengan kemauan sendiri maka akan dijatuhi hukuman sesuai perbuatannya, begitupun seseorang yang melakukan perbuatan kriminal hanya untuk membela diri ataupun keterpaksaan maka akan tetap disidangkan jika dipersidangan dinyatakan tidak melakukan tindak pidana secara terencana bahkan hanya sekedar membela diri maka hukumannya tidak terlalu tinggi. ${ }^{3}$

Seseorang yang telah ditentukan hukumannya maka tempat terakhirnya seseorang harus relah hidup berpisah dengan, anaknya, suaminya dan keluarganya berstatus narapidana dan harus menjalani kehidupan di Lembaga Pemasyarakatan selama waktu yang sudah ditentukan. Seseorang narapidana, yang sedang menjalani kehidupan di dalam Lembaga pemasyarakatan, tidak sedikit mengalami depresi, goncangan, dan penyesalan,dikarenakan mereka belum siap hidup di Lapas, yang sebelumnya tidak pernah dirasakan bahkan dibayangkan. Kondisi seperti ini biasa dialami kepada narapidana yang baru masuk Lembaga pemasyarakatan berstatus sebagai narapidana. Dalam kondisi seperti ini maka disinalah pungsi kegiatan keagamaan di tengah narapidana yang sedang menjalani kehidupan di Lembaga Pemasyarakatan. orang yang sedang menjalani hukuman

\footnotetext{
${ }^{3}$ Abdul Mujib; Jusuf Mudzakkir, Ilmu Pendidkan Islam, (Jakarta: Kencana Prenada Media, 2006), h. 256.
} 
akibat tindak pidana yang mereka perbuat. Karena salah satu kegiatan yang bersipat keagamaanlah yang dapat menentramkan jiwa seseorang, kegiatan keagamaanlah salah satu yang dapat membantu ketika berada pada kondisi tertekan dan dapat memberikan jalan keluar dan petunjuk kehidupan.

Kegiatan keagamaan adalah salah satu faktor untuk menyembuhkan seseorang dari penyakit-penyakit yang berkaitan dengan kemerosotan iman, dan bagi seseorang yang selalu menghiasi dirinya dengan kegiatan yang bersifat keagamaan maka mereka akan senantiasa mendapatkan petunjuk dan rahmat dari Allah swt.,

Kegiatan keagamaan dalam hal ini, diharapkan mampu menjadi problem solving dalam kehidupan pada manusia apalagi pada narapidana yang sedang menjalani hukuman akibat tindak kejahatan yang mereka perbuat. Allah swt., tetap menghendaki adanya peringatan, yaitu peringatan dalam bentuk bimbingan, pengaruh dan pemberian petunjuk kepada mereka yang pernah terlibat tindak pidana baik yang disengaja maupun tanpa kesengajaan, meskipun manusia telah melakukan penyimpangan atau penyelewengan terhadap ketentuan-ketentuan Allah (Sunnatullah). Oleh karena itu, manusia yang telah melakukan perbuatan yang menyimpang diharapkan kembali ke jalan yang benar dan baik dengan mematuhi hukum-hukum Allah swt., untuk kepentingan manusia, agar manusia dapat hidup dengan baik. ${ }^{4}$

Pemerintah Indonesia melalui Kementerian Hukum dan HAM mengubah pemaknaan narapidana yang selama ini kita ketahui menjadi warga binaan. Perubahan istilah warga binaan tersebut dilakukan guna mensejajarkan hak setiap warga negara Indonesia baik yang hidup diluar lingkungan penjara maupun di dalam wilayah binaan atau Lapas, khususnya hak untuk memperoleh pendidikan dan keterampilan dengan harapan para pelaku kriminalitas baik wanita maupun laki-laki dapat berinteraksi dengan masyarakat baik ketika masih menjalani hukuman maupun telah selesai menjalani hukuman, dan merubah perilaku negatif yang telah mereka lakukan setelah menjalani masa hukuman di Lembaga Pemasyarakatan atau yang biasa disebut Lapas. Lembaga Pemasyarakatan (LAPAS) memiliki tanggung jawab yang tidak ringan dalam menormalisasi kehidupan narapidana, ke arah yang lebih baik dari sebelumnya dan berakhlak mulia dan meninggalkan perilaku perilaku yang menyimpang yang pernah mereka perbuat

Program kegiatan perlu dilaksanakan, bahkan harus diutamakan. Kegiataan keagamaan adalah proses pemberian pemahaman agama tentang bagaimana perilaku-perilaku yang terpuji yang dapat membentuk pribadi sebagai manusia yang lebih baik dan berkualitas, serta mampu mengimplementasikan

\footnotetext{
${ }^{4}$ Anwar Arifin, Dakwah Kontemporer: Sebuah Studi Komunikasi, (Cet. I; Yogyakarta: Grahallmu, 2011), h. 4.
} 
nilai-nilai agama pada kehidupan pasca keluar dari Lembaga Pemasyarakatan (LAPAS). Pembentukan agama untuk narapidana menjadi pondasi yang memberikan mental dalam bermasyarakat agar narapidana dapat beradaptasi dengan masyarakat setelah keluar dari Lembaga Pemasyarakatan dengan akhlak yang lebih baik dari sebelumnya, dan ditunjang ilmu pengetahuan dan keterampilan yang mereka dapatkan di dalam Lembaga Pemasyarakatan. Ajaran agama Islam pembinaan akhlak merupakan masalah yang penting pada setiap individu maupun kelompok.

\section{PEMBAHASAN}

\section{A. Gambaran Lembaga Pemasyarakatan Wanita Kelas IIA Sungguminasa Gowa}

Lembaga Pemasyarakatan Wanita Kelas IIA Sungguminasa adalah salah satu Unit Pelaksana Teknis Pemasyarakatan di Wilayah Kerja Kantor Wilayah Kementerian Hukum dan HAM Sulawesi Selatan yang berlokasi di Jalan Lembaga - Bollangi Desa Timbuseng Kecamatan Pattalassang Kabupaten Gowa yang menempati lahan seluas $\pm 12.000 \mathrm{M}^{2}$ dengan Luas Bangunan secara keseluruhan $\pm 3.824 \mathrm{M}^{2}$. Lembaga Pemasyarakatan Wanita Kelas IIA Sungguminasa mulai dibangun pada Tahun 2004 dan mulai dioperasikan sejak 5 September 2007 serta diresmikan pada tanggal 26 Juli 2011 oleh Bapak Patrialis Akbar, S.H., Menteri Hukum dan HAM R.I.

\section{B. Kegiatan Keagamaan}

Kegiatan berasal dari kata dasar "giat" yang mendapat imbuhan "ke" dan akhiran "an" giat sendiri berarti aktif, bersemangat dan rajin. Kegiatan berarti aktifitas usaha atau pekerjaan ${ }^{5}$ Maka kegiatan dapat diartikan sebagai aktifitas, usaha atau pekerjaan yang dilakukan seseorang dalam rangka memenuhi kegiatannya.Keagamaan berasal dari kata dasar mendapat imbuhan "ke" dan akhiran "an" Agama sendiri berarti kepercayaan kepada tuhan sang pencipta dengan aturan syariat tertentu ${ }^{6}$ Dengan memperhatikan definisi yang ada di atas dapat disimpulkan bahwa kegiatan keagaman adalah suatu aktifitas yang berkenaan dengan kepercayaan kepada sang pencipta dengan tujuan untuk meningkatkan ketakwaan kepada sang khalik dengan hal ini kegiatan keagamaan yang di maksud adalah kegiatan keagamaan dalam Agama Islam.

Kegiataan keagamaan mempunyai peranan yang sangat penting dan sangat vital dalam rangka pembentukan manusia yang bertakwa dan taat kepada Allah swt. dalam rangka menjadikan manusia berakhlak mulia sesuai apa yang diperintahkan oleh Allah swt. kegiatan keagamaan sangatlah penting bagi segenap manusia agar manusia tidak menjadi makhluk primitif dalam artian manusia yang

\footnotetext{
${ }^{5}$ Alexma, Kamus Saku Bahasa Indonesia, (Jakarta: Tamer Press, 2013), h. 163.

${ }^{6}$ Alexma, Kamus Saku Bahasa Indonesia, h. 12.
} 
masih terbelakang tentang aailmu-ilmu pengetahuan keagamaan yang jauh dari nilai nilai akhlakul karimah dan tentunya kegiatan keagamaan sebagai suatu wadah dalam mengisi kehidupan ini agar seluruh aktifitas dalam keseharian bermanfaat dan tetntunya kegiatan keagamaan dapat memberikan pemahaman tentang hal yang berkaitan dengan ajaran keagamaan untuk menghindari perbuatan dosa karena tujuan penciptaan manusia di dunia ini yaitu untuk beriman dan bertaqwa.

Allah swt. memerintahkan manusia untuk bertakwa dan selalu memperhatikan gerak gerik perbuatanya tentang apa yang di perbuat apakah perbuataanya tidak menimbulkan dosa yang bisa mengakibatkan terjauh dari Allah swt., maka dalam hal ini agar kita senantiasa dalam tindakan yang baik perlu adanya kegiatan kegiatan keagamaan yang kita lakukan

Kegiatan keagamaan, adalah suatu hal yang harus ada di setiap sendi-sendi kehidupan dan disetiap langkah kehidupan ini tidak hanya di masjid dan di sekolah agama atau sekolah umum sebagai tempat utama penyelenggraan kegiatan keagamaan namun harus dihadirkan di setiap instansi, seperti Lembaga Pemasyarakatan yang notabene didalam Lapas terdapat orang yang bisa dikatakan masih dini tentang pengetahuan agamanya, untuk mendidik para narapidana agar menjadikan manusia yang berakhlak agar nantinya selepas menjalani masa hukuman dalam Lembaga Pemasyarakatan akan menjalani hidup seperti manusia pada umumnya, meskipun menurut pemahaman penulis tidak semuanya seseorang berada dalam lembaga pemasyarakatan karena merosotnya keimananan mereka miliki namun terkadang karena dijebak atau karena keterpaksaan contoh: membunuh seseorang karena terpaksa akibat ingin dirampok dan lain sebagainya. Namun kegiatan keagamaan di Lembaga Pemasyarakatan harus tetap ada dan bahkan harus ditingkatkan mengingat Lapas adalah suatu tempat dimana pelaku yang pernah melakukan tindak pidana ditempatkan dan mengisi harinya hingga bertahun-tahun maka sudah sepantasnya Lapas memilki segala fasilitas untuk menunjang kegiatan keagamaan untuk menciptakan manusia yang berkarakter dan beriman dan mematuhi segala aturan agama Islam

Kegiatan keagamaan adalah salah satu usaha yang terencana dan sistematis untuk mewujudkan dan mengembangkan potensi diri manusia untuk memiliki kekuatan spiritual keagamaan, pengendalian diri, kepribadian, kecerdasan, akhlak mulia serta keterampilan yang diperlukan dirinya, masyarakat, bangsa dan negara. $^{7}$

Berdasarkan kutipan di atas, penulis memahami dari apa yang di kemumakakan yang tertuan dalam Undang-Undang RI Nomor 20 tahun 2013, Sistem Pendidikan Nasional. Pasal 1, ayat (1). Yaitu pendidikan Islam dapat juga diartikan sebagai kegiatan keagamaan karena dalam pendidikan Islam terdapat

\footnotetext{
${ }^{7}$ Undang-undang RI Nomor 20 tahun 2013, Sistem Pendidikan Nasional Pasal 1, ayat (1)
} 
bentuk di dalamnya tentang ajaran keagamaan Islam yang pasti didasari dari al Qur'an dan hadist Rasurullah saw., dan kegiaatan keagamaan mempunyai pengaruh yang cukup vital untuk menjadikan manusia yang baik dan berakhlak karena

Melalui kegiatan keagamaan manusia akan mengetahui tentang konsep bagaimana hidup dengan baik, melalui kegiatan keagamaan manusia akan terampil melakukan berbagai cara dan melalui kegiaatan keagaamaan manusia akan mengendalikan dirinya dari perbuatan yang bisa merugikan dirinya dan bisa merusak Agama yang dianutnyaKegiatan keagamaan merupakan kegiatan yang memperbaiki perilaku dari perilaku jahat menuju keperilku yang baik dan kegiatan keagamaan. Membina budi pekerti luhur seperti, keikhlasan, kebenaran, keadilan, kejujuran, kasih sayang, cinta mencintai dan menghidupkan hati nurani manusia untuk memperhatikan Allah swt. ${ }^{8}$

Berdasarkan kutipan di atas, penulis berpendapat bahwa kegiatan keagamaan dapat memperbaiki tingkah laku, dari perilaku yang buruk menuju kearah perilaku yang baik karena kegiatan keagamaan terdapat pengajaran tentang kehidupan yang baik sesuai tuntunan Agama Islam yang berdasar dari al-Qur'an dan sunnah Nabi Muhammad saw. Manusia yang melakukan hal negatif, yang dilarang oleh agama maka semua hal seperti itu tidak akan lagi dilakukan ketika seseorang telah banyak mengetahui pemahaman agama karena dari pemahaman itu akan tumbuh rasa keimananan yang kuat dan tidak mudah untuk melakukan perbuatan yang menyimpang, maka sangat diharapkan dari kegiatan keagamaan yang dilakukan didalam Lembaga Pemasyarakatan menjadi sebuah tempat terciptanya manusia yang terampil, beriman dan meninggalkan segala perilku di masa silam yang pernah mereka perbuat.

\section{Bentuk Kegiatan Keagamaan di Lapas Wanita Kelas IIA Sungguminasa Gowa}

Menurut Ibu Ka Lapas, dalam pelaksanaab kegiatan keagamaan, pihak Lembaga Pemasyarakatn Wanita Kelas IIA Sungguminasa Gowa, juga telah melaksanakan upaya perencanaan, diantaranya menentukan waktu pelaksanaan kegiatan keagamaan, menyipakan sarana dan prasarana yang dibutuhkan dalam kegiatan keagamaan. Menentukan metode serta materi yang akan disampaikan kepada narapidana tentunya dengan berkordinasi dengan pihak uztadz dan uztadzah yang terjung lansung dalam menyampaikan materi. ${ }^{9}$

Berdasarkan dari penyampaian Ka Lapas, di atas penulis memahami bahwa dalam melaksanakan suatu kegiatan, waktu dan prasarana adalah suatu

\footnotetext{
${ }^{8}$ Muhammad Abdul Qadir, Metodologi Pengajaran Islam, (Jakarta: Bhineka Cipta, 2008), h. 7 .

${ }^{9}$ Sudaryati (56 tahun), Ka Lapas Wanita Kelas IIA Sungguminasa, Wawancara, Gowa 25 Mei 2018
} 
yang sangat penting untuk menunjang suatu kegiatan, bahkan bisa dikatakan kegiatan tidak akan terlaksana tanpa waktu dan sarana prasarana didalamnya.

Kegiatan keagamaan di Lembaga pemasyarakatan mempunyai peran yang cukup besar dalam membentuk para narapidana menjadi lebih baik, kegiatan keagamaan adalah usaha yang diarahkan untuk terbentuknya nilai-nilai ajaran islam pada diri, dan tercermin pada perilaku keseharian. Manfaat agama dalam kehidupan manusia berpengaruh dalam banyak aspek, bukan hanya aspek kerohanian saja. Manusia tanpa agama merupakan manusia yang tidak memiliki tujuan. Dalam ajaran agama, manusia dituntun agar senantiasa melakukan kebaikan dalam hidup. Dalam agama manusia diajarakan untuk saling tolong menolong antar manusia, saling toleransi dalam menerima keberagaman. Agama juga mengajarkan manusia untuk tidak melakukan hal yang merugikan orang lain maupun lingkungan.

Bentuk kegiatan keagamaan di Lembaga Pemasyarakatan Wanita Klas IIA Sunguminasa berdasarkan dari wawancara diberbagai elemen yang ada, baik dari Ka Lapas maupun petugas Lapas dan tentunya kepada uztadz dan uztadzah yang memberikan bimbingan langsung kepada narapidana dan para narapidana yang dibimbing oleh uztadz dan uztadzah.

Berdasarkan wawancara kepada Ka Lapas, bahwa kegiatan keagamaan di lembaga pemasyarakatan wanita kelas IIA Sungguminasa Gowa diadakan tiga kali dalam sepekan yakni hari senin, rabu, dan jum'at hari senin itu dilaksanakan oleh utusan dari Depag. Kab Gowa, dalam hal ini dilaksanakan oleh penyuluh Agama Uztadzah Hj. Masniati, dan pada hari rabu dilaksanakan oleh utusan Masjid AlMarkaz Syehk Yusuf yang dibimbing oleh Uztadz Ahmad Sudirman dan hari jum'at adalah jum'at ibadah yang dilaksanakan oleh Pemda Kab. Gowa dan pelaksannya tiap jum'at dinamakan jum'at ibadah dan pelaksananya berbedah beda orangnya yang datang tiap jum'at, tentunya ucapan terima kasih dari sejumlah uztadz dan uztadzah yang telah meluangkan waktunya untuk masuk memberikan bimbingan khususnya kegiatan keagamaan islam pada lembaga pemasyarakatan wanita kelas IIA Sungguminasa Gowa, dengan penuh keihklasan telah datang tanpa diberikan upah untuk bertujuan memberikan kegiatan keagamaan sumbangan ilmu pengetahuannya kepada narapidana. ${ }^{10}$

\section{Faktor Pendukung dan Penghambat Kegiatan Keagamaan di Lembaga Pemasyarakatan Wanita Kelas IIA Sungguminasa Gowa}

Pada setiap kegiatan keagamaan, pasti terdapat faktor pendukung begitupun faktor penghambat, faktor pendukung akan memberikan kontribusi yang sangat berarti dalam kegiatan keagamaan, begitup faktor penghambat akan menjadi hambatan pada kegiatan tersebut.

\footnotetext{
${ }^{10}$ Sudaryati (56 tahun) Ka Lapas Wanita Lapas Wanita Kelas IIA Sungguminasa, Wawancara, Gowa 25 Mei 2018
} 


\section{Faktor Pendukung}

Berdasarkan wawancara kepada Ibu Sudaryati, bahwa faktor pendukung pada kegiatan keagamaan di Lapas yaitu fasilitas Keagamaan di Lembaga Pemasyarakatan yang memang sudah sangat lengkap, adanya Pesantren di dalam Lapas yang dinamakan pesantren An-Nisa salah satu pendukung yang sangat utama dan di dalam pesantren An-Nisa terdapat Masjid yang sudah lumayan besar untuk ditempati dalam melaksanakan kegiatan keagamaan, dan disamping Masjid yang juga dinamakan Masjid An-Nisa terdapat perpusatkaan yang menampung ada beberapa buku-buku agama untuk bacaan menambah wawasan keilmuan, dan masjid yang sudah dilengkapi beberapa fasilitas pembantu seperti, sondsistem, kipas angin, dan sarana dalam menjalankan kegiatan keagamaan seperti mukena, al-Qur'an dan sajadah dll. ${ }^{11}$

Menurut Muhajir, bahwa faktor pendukung kegiatan keagamaan yang juga tidak kalah pentingnya adalah beberapa pembimbing yang memang melungkan waktunya dan ilmunya membimbing kepada para narapidana, yang memang pembimbing tersebut datang rutin dalam setiap 1 x sepekan dan dijadwalkan oleh pihak lapas, dan dari berbagai elemen ada yang dari pihak kementrian Agama Kabupaten Gowa, ada dari pihak uztadz utusan Masjid Al-Markaz Jenderal Yusuf dan ada dari pihak Pemerintah Daerah Kabupaten Gowa dan berlatar belakang mulai dari S1 agama Sampai S3 Agama. ${ }^{12}$

\section{Faktor Penghambat}

Faktor penghambat kegiatan keagamaan juga datang dari para narapidana itu sendiri, misalkan ada beberapa narapidana yang tidak pernah dibesuk oleh keluarganya, entah dengan alasan karena jauh atau karena keluarganya juga orang yang ekonomi rendah, sehingga tidak bisa membesuk keluarganya. Jadi narapidana tersebut ketika tidak ada besukan maka otomatis dia tidak mempunyai uang, maka secara tidak lansung berdampak juga pada kegiatan keagamaannya misalkan para narapidana yang ingin melakukan shalat pasti harus pakai mukena, ketika narapidana yang tidak mempunyai mukena maka harus menunggu dulu antri untuk meminjam mukena temannya. Menurut hj. Masniati beliau biasa memintakan mukena bekas kepada teman-temanya dan keluarganya untuk diberikan kepada narapidana yang tidak mempunyai mukena dikarenakan tidak pernah ada besukan dari keluarganya.

Muhajir pun menambahkan sebagai salah satu pegawai yang mendampingi lansung para uztadz dan uztadzah ketika memberi kegiatan, faktor penghambat kegiatan keagamaan adalah waktu yang cukup minim, artinya kegiatan

\footnotetext{
${ }^{11}$ Sudaryati (56 tahun) Ka Lapas wanita Lapas Wanita Kelas IIA Sungguminasa, Wawancara, Gowa 25 Mei 2018

${ }^{12}$ Muhajir (38 tahun), pegawai Binadik Lembaga Pemasyarakatan wanita Kelas IIA Sungguminasa, Wawancara, Gowa, 30 Mei, 2018.
} 
keagamaan di Lapas Wanita Sungguminasa Gowa ini, dibatasi hanya mulai jam 09 pagi sampai menjelang dhuhur dan setelah dhuhur maka tidak ada lagi kegiatan keagamaan. $^{13}$

Faktor penghambat lainya, adalah karakter narapidana yang berbeda beda, ada sebagian narapidana ketika diberikan bimbingan tenang dalam mendengarkan, adapun narapidana yang cukup banyak bergerak kadang banyak berbicara dengan temannya yang lain. Adapula narapidana yang susah diajak mengikuti kegiatan keagamaan. Narapidana seperti ini adalah narapidana yang biasanya baru masuk di lembaga, mungkin masih mengingat suasana diluar lembaga sehingga belum bisa menerimah dengan baik. ${ }^{14}$

\section{III.PENUTUP}

Bentuk kegiatan keagamaan di Lembaga pemasyarakatan Wanita Sungguminasa Gowa, terdiri dari beberapa bentuk kegiatan dan dibimbing dari beberapa uztadz dan uztadzah dari berbagai elemen ada dari Departemen Agama Kab. Gowa, yang dilaksanakan oleh penyuluh Agama, ada dari Dai utusan Masjid Al-Markaz Jenderal Yusuf dan dari pemerintah Daerah Kab Gowa dalam hal ini dilaksanakan oleh bidang Sosial Keagamaan dan spiritual. Adapun para pembimbing uztadz dan uztadzah telah diberikan masing-masing jadwal bimbingan oleh pihak Lapas. Pembimbing dari pihak Kementerian Agama Gowa dilaksanakan oleh uztadzah $\mathrm{Hj}$. Masniati yang memberikan bimbingan, BTQ dan Fiqhi Ibadah pada hari selasa. Sedangkan pembimbing dari utusan Dai Masjid AlMarkaz Jenderal Yusuf dilaksanakan oleh Uztadz Ahmad Sudirman yang memberikan bimbingan Tadarrus Qur'an pada hari pada hari kamis, dan Jum'at ibadah yang dilaksanakan oleh pihak pemda Kabupaten Gowa dalam hal ini Bidang keagamaan dan Spiritual piham Pemda Gowa mengirim uztadz dan uztadzah stiap jum'at ke Lapas Wanita Sungguminasa Gowa dan uztadz yang di utus ke Lapas setiap jum'at berbeda beda dan tema yang diberikan oleh uztadz dan uztadzah yang di utus oleh Pemda Kabupaten Gowa Bidang Keagamaan dan Spiritual adalah tentang banyak-banyak pemberian motivasi kepada para narapidana.

Hasil dari Kegiatan Keagamaan sebagai Pilar Perbaikan Perilaku Narapidana Wanita Kelas IIA Sungguminasa Gowa, berdasarkan penelitian penulis, sudah menunjukkan perkembangan yang baik perlahan lahan para narapidana yang betul-betul giat dalam mengikuti bimbingan menunjukkan perubahan pada pemahaman, wawasan serta perilakunya, bahkan banyak yang terjadi para narapidana yang awalnya tidak tahu membaca Al-Qur'an setelah terus

\footnotetext{
${ }^{13}$ Muhajir (38 tahun), Pegawai Binadik Lembaga Pemasyarakatan wanita Kelas IIA Sungguminasa, Wawancara, Gowa, 30 Mei, 2018.

${ }^{14}$ Masniati (50 tahun), penyuluh, Departemen Agama Kab Gowa, Wawancara, Gowa 25 Mei 2018
} 
menerus dibimbing hingga akhirnya dalam lapas mereka bisa membaca AlQur'an.

Faktor pendukung kegiatan keagamaan di Lembaga Pemasyarakatan Wanita Kelas IIA Sungguminasa Gowa, berdasarkan dari hasil penelitian penulis yaitu, adalah Pondok Pesantren An-Nisa yang ada di dalam Lapas salah satu faktor pendukung yang utama, pada Pondok Pesantren An-Nisa dilengkapi berbagai fasilitas seperti Masjid yang sudah lengkap, kipas angin air untuk dipakai berwudhu, mukena, Al-Qur'an dan hadirnya para pembimbing dari luar yang yang memang dari berbagai elemen dan latar belakang pendidikan agama yang mereka kuasai rata-rata pembimbing berlatar belakang Magister dalam bidang Agama. Faktor penghambat, Kegiatan Keagamaan di Lembaga Pemasyarakatan Wanitac Kelas IIA Sungguminasa Gowa, berdasarkan dari hasil penelitian penulis yaitu, kurangnya anggaran dari pemerintah pusat dalam setiap kegiatan keagamaan, pegawai-pegawai yang bertugas di Lapas berlatar belakang pendidikan umum sehingga ketika para pembimbing dari luar berhalangan datang tidak bisa diisi oleh pegawai lapas, dan faktor penghambat lainya datang dari karakter narapidana yang berbeda beda ada 


\section{DAFTAR PUSTAKA}

Aat Syafaat; Sohari Sahrani; Muslih, Peranan Pendidikan Agama Islam, Jakarta: PT. Raja Grafindo Persada, 2008.

Abdul Mujib; Jusuf Mudzakkir, Ilmu Pendidkan Islam, Jakarta: Kencana Prenada Media, 2006.

Ahmad Muhammad Abdul Qadir. Metodologi Pengajaran Agama Islam, Jakarta: Rineka Cipta, 2008.

Ali, Mohammad Daud. Pendidikan Agama Islam. Ed.I; Jakarta: Rajawali Pers, 2008 .

Al-Rasyidin dkk, Pendekatan Historis, Teoritis dan Praktis Filsafat Pendidikan Islam Jakarta: Ciputat Press, 2005.

Al-Rasyidin, Samsul Nizar, Filsafar Pendidikan Islam, Cet.II; Jakarta: PT Ciputat Press, 2005.

Anwar Arifin. Dakwah Kontemporer: Sebuah Studi Komunikasi Cet. I; Yogyakarta: GrahaIlmu, 2011.

Anwar, Rosihan. Akidah Akhlak. Cet. I; Bandung: CV. Pustaka Setia, 2008.

Arief, Barda Nawawi. Bunga Rampai Kebijakan Pidana. Bandung: PT Citra Aditya Bakti, 1996.

Ary H. Gunawan, kebijakan-kebijakan Pendidikan di Indonesia, Cet. IV Jakarta:Bina Aksara,1986.

Bakti, 2002.

Chazaw, Adami. Pelajaran Hukum Pidana. Cet.7. Jakarta: PT Raja GrafindoPersada, 2012.

Darajat Zakiyah, Dkk, Metodik Khusus Pengajaran Agama Islam Jakarta: Bumi Aksara, 2008.

Darajat Zakiyah, Dkk, Metodik Khusus Pengajaran Agama Islam Jakarta: Bumi Aksara, 2008.

Djisman Samosir, D. Sekelumit Tentang Penologi dan Pemasyarakatan. Bandung: Nuansa Aulia. 2012.

El-Muhtaj, Majda. Hak Asasi Manusia dalam Konstitusi Indonesia. Jakarta: Kencana Prenada Media Group. 2005.

Fadli Andi Natsif,. Hukum dan Hak Asasi Manusia. Makassar: Bahan Power Point Kuliah). 2014. 
Fadli Andi Natsif,. Kejahatan HAM Perspektif Hukum Pidana Nasional dan Hukum Pidana Internasional. Jakarta: PT Rajagrafindo Persada. 2016.

Harlis Kurniawan, Konseling Terapi, (Jakarta: Gema Insani, 2005.

Hasan Asari, Hadis-Hadis Pendidikan Sebuah Penelusuran Akar-Akar Ilmu Pendidikan Islam Bandung: Citapustaka Media Perintis, 2014.

Hasan, Hamzah. Hukum Pidana Islam. Makassar : Alauddin University Press, 2014.

http://kamushukumonline.com/narapidana diakses pada tanggal 17 Januari 2018, pukul 15.30 Wita.

http://kbbi.web.id/narapidana diakses pada tanggal 17 Januari 2018, pukul 15.30 Wita.

Imam al-Ghazali, Ihya' Ulumuddin juz III Semarang: Usaha Keluarga.

Imam Suprayogo dan Tobroni, Metodologi Penelitian Sosial-Agama Bandung: Remaja Rosdakarya, 2001.

Kementerian Agama RI. al-Qur'an dan Terjemahnya.

Kumkelo, Mujaid dkk. Fiqh HAM. Malang, Jawa Timur: Setara Press. 2015.

Lamintang. Hukum Panitensier Indonesia edisi kedua. Cet.II. Jakarta: Sinar Grafika, 2012.

Lexy J. Moleong, Metodologi Penelitian Kualitatif edisi revisi.

M. Arifin, Ilmu Pendidikan Islam Ad. I. Cet.V; Jakarta: Bumi Aksara, 2009.

Muhaimin. Paradigma Pendidikan Islam. Bandung: Remaja Rosdakarya, 2004.

Naro Wahyudin, pendidikan karakter dalam perspektif Islam Alauddin University Pres, 2014.

Nasution Harun, Ensiklopedia Islam Indonesia Cet. I; Jakarta: Djambatan, 1992.

Nata Abuddin, Mengatasi Kelemahan Pendidikan Islam di Indonesia, Edisi Kedua,Jakarta : Prenada Media Group 2008.

Nata Abudin, Filsafat Pendidikan Islam Jakarta: Gaya Media Pratama, 2005.

Pengantar kurikulum PAI. Jakarta: PT. Raja Grafindo Persada, 2009.

Priatno, Dwidya. Sistem Pelaksanaan Pidana Penjara di Indonesia. Cet.III Bandung:Refika Aditama, 2013.

Ridwan, Belajar Mudah Penilitian Untuk Guru-Kariawan dan peneliti pemula Cet VIII; Bandung: Alfabeta, 2012. 
Ruslan Renggong, Hukum Acara Pidana. Jakarta: Prenada Media Group, 2014. Sahetapy, J.E. Pidana Mati dalam Negara Pancasila. Bandung: PT. Citra Aditya Sampara, Said. Pengantar Ilmu Hukum. Yogyakarta: Total Media, 2009.

Sarjono Soekamto, Kamus Sosiologi, Jakarta: Raja wali Press, 2000,

Sugiono, Memahami Penelitian Kualitatif Cet.VIII; Bandung: Alfabeta, 2013.

Sugiono, Metode Penelitian Kuantitatif, Kualitatif dan R\&D

Sugiyono, Metode Penelitian Pendidikan:Pendekatan Kuantitatif, Kualitatif, dan $R \& D$ Cet. XIV; Bandung: Alfabeta, 2012.

Suharsimi arikanto, Prosedur Penelitian Suatu Pendekatan, Jakarta: Bumi Aksara, 2009. 